Laurence J. Kotlik off is a professor of economics at Boston University and a research associate at the National Bureau of Economic Research. J effrey Sachs is a professor of economics at Harvard University.

\section{The Personal Security System: A Framework for Reforming Social Security}

\author{
Laurence J. Kotlikoff and \\ J effrey Sachs
}

de

he U.S. Social Security System is in urgent need of reform. It has a massive long-term deficit that cannot be covered without major payroll tax hikes or significant benefit cuts. For example, paying for Social Security benefits on an ongoing basis requires an immediate and permanent 4.7 percentage-point increase in the payroll tax rate. Since the current tax rate is 12.4 percent, this represents a 40 percent tax hike. This is more than twice the requisite tax hike reported by the Social Security Trustees. Their half-truth about Social Security finances reflects the use of a truncated planning horizon. In addition to being effectively insolvent, the Social Security System is also inefficient, inequitable, uninformative, and outmoded.

Our plan, the Personal Security System (PSS), would redress these problems by replacing the Old-Age Insurance (OAI) portion of Social Security with a system of individual accounts and by establishing a dedicated stream of revenues to pay off the current system's unfunded liability. Simulations of this approach to Social Security reform show substantial long-run improvements in U.S. living standards. These gains reflect a partial alleviation of the enormous fiscal burden that future generations will face as a result of current entitlement programs. Because precise analysis of any Social Security reform requires the use of the Social Security Administration's extensive databases, we strongly urge Congress to instruct the
Social Security Administration to undertake a detailed analysis of this proposal.

THE PSS PROPOSAL

The following paragraphs provide highlights of our proposal for partial reform of the current system.

\section{Scope}

Only the OAI payroll tax (about 70 percent of total OASDI contributions) is eliminated in the PSS plan. Contributions to and benefits from the DI (Disability Insurance) and SI (Survivors Insurance) portions of the Social Security System are completely unchanged.

\section{Ea rnings Sharing}

To protect nonworking spouses as well as spouses who are secondary earners, total PSS contributions made by married couples would be split 50-50 between the husband and wife before being deposited in PSS accounts.

\section{Government Matching of Contributions}

Under the PSS plan, the federal government would match contributions of lowincome contributors on a progressive basis. It would also make PSS contributions on behalf of disabled workers through age 65 .

\section{Tax Treatment}

PSS contributions would be subject to the same tax treatment as current $401(k)$ accounts. Contributions would be deductible and withdrawals taxable.

\section{Survivor Provisions}

Provisions governing PSS balances for survivors through age 60 are identical to those governing $401(\mathrm{k})$ accounts. 
Investment of Account Balances

Workers and their spouses would invest their PSS contributions in regulated, supervised, and diversified investments. For example, these investments might be restricted to a market-weighted global index fund of stocks, bonds, and real estate. PSS contributors could buy this security from any approved financial institution. Competition would drive down the transaction fees to very low levels. Forcing all PSS participants to purchase the global index fund ensures their holding of a fully diversified portfolio and prevents them from trying to "time the market."

\section{Annuitization of Account Balances}

PSS balances could not be withdrawn prior to age 60. Between ages 60 and 70 , the PSS account balance would be pooled with those of other cohort members and jointly annuitized. This would be done on a daily basis, so that by the time the cohort reached age 70, all of its balances would be annuitized. The annuities would be singlelife and indexed against inflation. The federal government would oversee this annuitization process and put it out for competitive bids. This method of converting PPS balances into real annuities precludes adverse selection and ensures low transaction cost.

\section{Payment of Social Security Benefits to Current Retirees}

Current recipients of Social Security retirement benefits would continue to receive their full inflation-indexed benefits.

\section{Payment of Accrued Social Security Benefits to Current Workers}

When they reach retirement, workers would receive the full amount of Social Security retirement benefits that they had accrued as of the time of the reform. For each year after the transition, Social Security benefits would be calculated by filling in zeros in the OAI earnings records of all participants. Since new workers joining the work force would have only zeros entered in their OAI earnings histories, they would receive no OAI benefits in retirement. This ensures that over a transition period aggregate Social Security retirement benefits would decline to zero.

\section{Financing the Transition}

During the transition, Social Security retirement benefits would be financed by a business cash-flow tax. This tax, which is in effect a consumption tax, would also finance the government's PSS contribution match. Over time, the PSS tax rate would decline as the amount of Social Security retirement benefits declined. Provisional calculations suggest that the tax would begin below 10 percent and would decline to a permanent level of roughly 2 percent within 40 years.

\section{THE PSS PLAN IN}

\section{PERSPECTIVE}

Obviously, any proposal to reform the current Social Security System needs to be examined in the light of national values and potential economic impact. The following are some major points that should be considered in evaluating the PSS plan.

\section{Advantages of the Reform}

The Personal Security System would improve benefit-tax linkage, enhance survivor protection, equalize treatment of one- and two-earner couples, offset the ongoing transfer of resources from the young to the old, provide better divorce protection to nonworking spouses, make the system's progressivity transparent, resolve Social Security's long-term funding problem, and ensure Americans an adequate level of retirement income at minimum transaction costs.

\section{Macroeconomic Effects}

Simulation studies suggest that this reform would, over time, increase the economy's output by roughly 15 percent and its capital stock by roughly 45 percent. 
Impact on the Poor

Social Security's cost-of-living adjustment insulates its beneficiaries from the potential increase in consumer prices associated with the introduction of the PSS tax. Hence, those who are currently elderly and poor would experience no higher fiscal burden. Moreover, simulation analysis shows that the poor who are currently middle-aged or young, as well as poor members of future generations, have the most to gain from privatizing Social Security.

\section{Intergenerational Equity}

The PSS proposal asks current Americans, old and young alike, to contribute to paying off Social Security's unfunded retirement benefit liability. Since it insulates the current poor elderly, only rich and middle class elderly would face a higher fiscal burden. Asking them to pay their share of Social Security's unfunded liability is intergenerationally equitable, particularly given the massive and growing M edicare-financing burden that future generations face.

\section{Comparison with 0 ther}

\section{Reform Proposals}

Unlike many other Social Security reform proposals, the Personal Security System would substantially al leviate the long-run fiscal crisis facing future generations. It would also improve economic efficiency by linking retirement income to retirement saving without sacrificing secondary earners and the poor.

\section{THE CHALLENGE}

\section{FACING THE CONGRESS}

All major Social Security reform proposals, as well as the current system, need to be compared on a systematic basis with respect to intergenerational burdens, fiscal sustainability, economic efficiency, and intragenerational equity. Congress should instruct the Social Security Administration to perform this analysis in consultation with the Congressional Budget Office and other agencies of the U.S. government. 